\title{
Pregnancy onset congenital thrombotic thrombocytopenic purpura (Upshaw-Schulman syndrome) mimicking HELLP syndrome: a case report
}

\author{
Başak Ergin ${ }^{1}$ (D), Berna Buse Kobal ${ }^{2}$ (D) , Zeynep Yazıcl ${ }^{2}$ (D) , Ali Hakan Kaya ${ }^{3}$ (D), \\ Sezin Canbek ${ }^{4}$ (D), Murat Muhcu² (iD), Ayşegül Özel ${ }^{2}$ (D) \\ 1Obstetrics and Gynecology Clinic, Reşadiye State Hospital, Tokat, Turkey \\ ${ }^{2}$ Department of Obstetrics and Gynecology, Ümraniye Training and Research Hospital, University of Health Sciences, Istanbul, Turkey \\ ${ }^{3}$ Department of Hematology, Ümraniye Training and Research Hospital, University of Health Sciences, Istanbul, Turkey \\ ${ }^{4}$ Department of Medical Genetics, Ümraniye Training and Research Hospital, University of Health Sciences, Istanbul, Turkey
}

\begin{abstract}
Objective: Thrombotic thrombocytopenic purpura is a thrombotic microangiopathic condition characterized by hemolytic anemia, thrombocytopenia, neurologic abnormalities, fever and renal dysfunction. Thrombotic microangiopathies such as preeclampsia and HELLP syndrome are pregnancy-specific, whereas others such as thrombotic thrombocytopenic purpura (TTP) and hemolytic uremic syndrome are not. In this report, we present a case at which we identified a novel mutation which led to a significant reduction of ADAMTS13 activity.

Case: A nulliparous pregnant woman of 32-year-old presenting with epigastric pain, hypertension and low platelet count was first suspected of HELLP syndrome, but was diagnosed with congenital TTP after delivery.

Conclusion: HELLP syndrome co-existed with undiagnosed TTP in this case. We strive to have sufficient awareness in order to distinguish these two pathologies from each other on an antenatal basis, because the causes of the managements are entirely different.
\end{abstract}

Keywords: ADAMTS13 activity, congenital thrombotic thrombocytopenic purpura, HELLP syndrome, outcome, plasmapheresis, pregnancy.
Özet: HELLP sendromunu taklit eden gebelik bașlangıclı konjenital trombotik trombositopenik purpura (Upshaw-Schulman sendromu): Olgu sunumu

Amaç: Trombotik trombositopenik purpura; hemolitik anemi, trombositopeni, nörolojik anomaliler, ateş ve renal disfonksiyon ile karakterize trombotik mikroanjiyopatik bir hastalıktır. Preeklampsi ve HELLP sendromu gibi trombotik mikroanjiyopatiler gebeliğe özgüyken, trombotik trombositopenik purpura (TTP) ve hemolitik üremik sendrom gibi diğer mikroanjiyopatiler gebeliğe özgü değildir. Bu raporda, ADAMTS13 aktivitesinde önemli bir azalmaya yol açan yeni bir mutasyon tespit ettiğimiz olgumuzu sunuyoruz.

Olgu: Epigastrik ağrı, hipertansiyon ve düşük platelet sayısıyla başvuran 32 yaşındaki nullipar gebede önce HELLP sendromundan şüphelenildi, fakat olguya doğum sonrasında konjenital TTP tanisı ald1.

Sonuç: Bu olguda tanı almamış TTP'nin yanı sıra HELLP sendromu mevcuttu. İki patolojiyi antenatal bir temelde birbirinden ayırt edebilmek için yeterli farkındalığa sahip olmaya çalışmaktayız, çünkü iki patolojinin yönetim nedenleri birbirinden tamamen farklıdır.

Anahtar sözcükler: ADAMTS13 aktivitesi, konjenital trombotik trombositopenik purpura, HELLP sendromu, sonuç, plazmaferez, gebelik.

\section{Introduction}

Congenital thrombotic thrombocytopenic purpura (TTP) also known as Upshaw-Schulman syndrome (USS) is an ADAMTS13 deficiency (disintegrin-like and met-

alloproteinase with thrombospondin patterns type 1-13) activity due to genetic mutations. Impaired activity of this enzyme causes accumulation of ultralarge von Willebrand factor in the circulation. This molecule

Correspondence: Ayşegül Özel, MD. Department of Obstetrics and Gynecology, Ümraniye Training and Research Hospital, University of Health Sciences, Istanbul, Turkey. e-mail: ozelaysegul@hotmail.com / Received: October 14, 2021; Accepted: November 17, 2021

How to cite this article: Ergin B, Kobal BB, Yazıcı Z, Kaya AH, Canbek S, Muhcu M, Özel A. Pregnancy onset congenital thrombotic thrombocytopenic purpura (Upshaw-Schulman syndrome) mimicking HELLP syndrome: a case report. Perinatal Journal 2021;29(3):270-273. doi:10.2399/prn.21.0293013 
binds the platelets and leads to the microvascular thrombus that results in organ failure, thrombocytopenia, hemolytic anemia, or death when left untreated. ${ }^{[1]}$ Thrombotic microangiopathies such as preeclampsia and HELLP (hemolysis, elevated liver enzymes, low platelet count) syndrome are pregnancy specific, whereas others such as TTP and hemolytic uremic syndrome (HUS) are not. ${ }^{[2]}$ It can be extremely difficult to differentiate these pathologies from each other due to overlap in clinical and laboratory manifestations especially in late second or third trimester of pregnancy. Hereby we presented a case of pregnancy-onset TTP that misdiagnosed and managed as HELLP syndrome.

\section{Case Report}

At the 28th gestational week, a 32-year-old nulliparous pregnant woman was admitted to our clinic following epigastric pain that lasts for a week. There was not any pathologic condition in her medical history, there was a missed abortion in her obstetric history. Physical examination revealed blood pressure of 150/90 $\mathrm{mmHg}$. Ultrasound confirmed positive fetal heart activity, but abdominal circumferences and estimated of fetal weight were at $3.2 \%$ and $4.8 \%$ percentile, respectively. Umbilical artery Doppler measurement revealed absent end diastolic flow. Laboratory tests showed hemoglobin 9.3

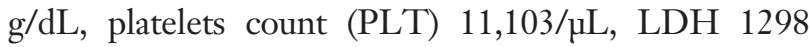
IU/LIU/mL, SGOT 75 IU/L, SGPT 75 IU/L, serum creatinine $1.57 \mathrm{mg} / \mathrm{dL}$ and spot urine protein/creatinine rate 2.09 .

She received one pool of platelets and one packed of apheresis platelets. Betamethasone applied for fetal lung maturation prophylaxis and magnesium sulphate applied for maternal eclampsia prophylaxis. Due to persistency of high blood pressure and epigastric pain we rushed to cesarean delivery with diagnosis of HELLP syndrome after checking the new platelet count $(51,103 / \mu \mathrm{L})$. A 810 gram live baby was delivered. At the first postpartum day, PLT increased to $118,103 / \mu \mathrm{L}$ along with improvement of liver enzyme levels and LDH level. At the fourth postpartum day, PLT dropped back to $25,103 / \mu \mathrm{L}$ and $\mathrm{LDH}$ increased to $1270 \mathrm{IU} / \mathrm{L}$. Peripheral blood smear revealed $3-4 \%$ schistocytes.

The patient was consulted to hematology department. Since TTP was strongly suspected, a blood sample was taken to analyze ADAMTS13 activity, and plasmapheresis protocol was started at the dosage of 40 $\mathrm{ml} / \mathrm{kg}$. ADAMTS-13 activity results became available at the 9th postpartum day. ADAMTS-13 activity levels were found to be very low $(0.02 \mathrm{IU} / \mathrm{ml}$, standard range 0.4-1.3 IU/ml). ADAMTS-13 antibody levels were found to be negative $(5.11 \mathrm{U} / \mathrm{ml}$, negative result $<12$ $\mathrm{U} / \mathrm{ml}$ ). ADAMTS-13 mutation analysis has been performed to reveal the exact nature of this type of TTP.

We have applied the usage of Clinical Exome Solution V2 kit (Sophia Genetics SA, Saint-Sulpice, Switzerland) for proper exome enrichment, along with all of the procedures being carried out in accordance with the manufacturer's protocols. The nature and mechanics of this target enrichment kit is known to cover 4490 genes, which are known to be the cause of a myriad of genetic based diseases and syndromes. Paired-end sequencing was performed on a NextSeq 500 system (Illumina, San Diego, CA, USA) with a read length of $150 \mathrm{bp}$, while the base calling and image analysis were conducted using real-time analysis (integrated to the NextSeq 500 system; Illumina) software. The BCL (base calls) binary is converted into FASTQ utilizing the Illumina package bcl2fastq. All bioinformatics analyses were performed on a Sophia DDMTM platform (Sophia Genetics SA). Alignment of reads to hg19, variant and copy number variation calling and annotation were carried out by algorithms MokaTM, PepperTM and MuskatTM (Sophia Genetics SA). Variants obtained were then investigated thoroughly by using population frequency databases (1000G, ESP, ExAC, gnomAD), bioinformatics tools that assess the impact of the variant on the protein (SIFT, PolyPhen, MutationTaster, PhyloP) and clinical databases (OMIM, ClinVar). Novel variants (c.302_303del and c.1013 A>G) in the ADAMTS13 gene were detected in the proband. After 9 sessions PLT raised to $282,103 / \mu \mathrm{L}$. The patient was kept for 15 day in the hematology clinic, then discharged in good condition on the 25 th day of postpartum.

\section{Discussion}

Preeclampsia refers to the new onset of hypertension and proteinuria or the new onset of hypertension and significant end-organ dysfunction with or without proteinuria after 20 weeks of gestation or postpartum in a previously normotensive woman. The diagnosis of preeclampsia with severe features (formerly severe preeclampsia) is made in the subset of women with preeclampsia who have severe hypertension and/or 
specific signs or symptoms of significant end-organ dysfunction that signify the severe end of the preeclampsia spectrum. HELLP syndrome probably represents a type of preeclampsia with severe features in which hemolysis, elevated liver enzymes, and thrombocytopenia are the predominant features rather than hypertension or central nervous system or renal dysfunction, although the latter do occur. The majority of patients, but not all, have hypertension ( 82 to 88 percent) and/or proteinuria (86 to 100 percent). ${ }^{[3]}$ TTP is a life-threatening multisystem disease characterized by microangiopathic hemolytic anemia, thrombocytopenia, neurologic abnormalities, fever, and renal dysfunction. The incidence of TTP-related severe ADAMTS13 deficiency is at least 1:198,000 pregnancies. $^{[4]}$ This rate is reported previously higher because included either HUS and TTP with no documentation of ADAMTS13. ${ }^{[4-6]}$

When first TTP boot occurs in pregnancy, it is not always possible considered in differential diagnosis as in our case and similarly other cases. ${ }^{[7,8]}$ However, pregnancy is a condition in 17 percent of women of childbearing age with TTP, and most of these women experience their first TTP episode during the second trimester of pregnancy or postpartum period. ${ }^{[2,4,9]}$ HELLP syndrome is complicating pregnancies, approximately 200 times more than TTP. The association of HELLP syndrome with TTP is complex and can present in different forms. HELLP syndrome coexisted with undiagnosed TTP in this case. Concurrent existence rate was reported in about $17 \%$ with higher mortality rate when compared with cases with pure TTP, probably cause of delaying in diagnosis or in the initiation of plasmapheresis. ${ }^{[10]}$ To distinguish TTP from HELLP syndrome has critical importance because its managements are completely different. Although plasmapheresis is the optimal treatment for TTP, it is a definitive treatment for HELLP syndrome. The condition will continue to deteriorate in TTP unless plasmapheresis is started even the patient was delivered as we experienced in this case.

Failure to respond to high-dose corticosteroids and need to more intensive immunosuppressive treatment with other drugs can be clues for differentiating. A significant degree of severe thrombocytopenia and elevated levels of AST and LDH, which are atypic for HELLP syndrome, can be another symptom of TTP.
In the presence of these clues, initiating emergent plasmapheresis might be a life-saving factor while ADAMTS13 confirmation is awaited. ${ }^{[7,11]}$ Stillbirth rate was reported very high $(\% 60)$ closely related to gestational week or trimester during which the TTP episode occurs. In the USS patients, subsequent pregnancies led with no prophylaxis were associated with a $66 \%$ abortion rate and a $100 \%$ risk for TTP relapse. ${ }^{[4]}$

\section{Conclusion}

In conclusion, we studied with multidisciplinary (obstetrics, hematology, genetics) approach, and identified a novel mutation which led to a significant reduction of ADAMTS13 activity. By demonstrating the diagnosis of congenital TTP via genetic analysis, we will be able to planning and applying plasmapheresis in case of relapse regarding the subsequent pregnancy of the patient. So, we will be able to reach delivery at term with a much better perinatal outcome. Clinicians should be expected to assess and determine the ADAMTS13 activity in the setting of HELLP syndrome, even in retrospective circumstances, as these assessments may elucidate proper diagnosis, allow the prevention of maternal morbidity/mortality and thus resulting to successful childbirth.

Funding: This work did not receive any specific grant from funding agencies in the public, commercial, or not-for-profit sectors.

Compliance with Ethical Standards: The authors stated that the standards regarding research and publication ethics, the Personal Data Protection Law and the copyright regulations applicable to intellectual and artistic works are complied with and there is no conflict of interest.

\section{References}

1. Roose E, Tersteeg C, Demeersseman R, Schelpe A, Deforche L, Pareyn I, et al. Anti-ADAMTS13 antibodies and a novel heterozygous p.R1177Q mutation in a case of pregnancy-onset immune-mediated thrombotic thrombocytopenic purpura. TH Open 2018;2:e8-e15. [PubMed] [CrossRef]

2. McCrae KR. Thrombocytopenia in pregnancy. Hematology Am Soc Hematol Educ Program 2010;2010:397-402. [PubMed] [CrossRef]

3. Sibai BM. Diagnosis, controversies, and management of the syndrome of hemolysis, elevated liver enzymes, and low platelet count. Obstet Gynecol 2004;103:981-95. [PubMed] [CrossRef]

4. Moatti-Cohen M, Garrec C, Wolf M, Boisseau P, Galicier L, Azoulay E, et al.; French Reference Center for Thrombotic Microangiopathies. Unexpected frequency of UpshawSchulman syndrome in pregnancy-onset thrombotic throm- 
bocytopenic purpura. Blood 2012;119:5888-97. [PubMed] [CrossRef]

5. Zheng XL, Sadler JE. Pathogenesis of thrombotic microangiopathies. Annu Rev Pathol 2008;3:249-77. [PubMed] [CrossRef]

6. Tsai HM. Pathophysiology of thrombotic thrombocytopenic purpura. Int J Hematol 2010;91:1-19. [PubMed] [CrossRef]

7. Rehberg JF, Briery CM, Hudson WT, Bofill JA, Martin JN Jr. Thrombotic thrombocytopenic purpura masquerading as hemolysis, elevated liver enzymes, low platelets (HELLP) syndrome in late pregnancy. Obstet Gynecol 2006;108:81720. [PubMed] [CrossRef]

8. Ramadan MK, Badr DA, Hubeish M, Itani S, Hijazi H, Mogharbil A. HELLP syndrome, thrombotic thrombocytopenic purpura or both: appraising the complex association and proposing a stepwise practical plan for differential diagnosis. J Hematol 2018;7:32-7. [PubMed] [CrossRef]

9. George JN. The association of pregnancy with thrombotic thrombocytopenic purpura hemolytic uremic syndrome. Curr Opin Hematol 2003;10(5):339-44. [PubMed] [CrossRef]

10. Martin JN Jr, Bailey AP, Rehberg JF, Owens MT, Keiser SD, May WL. Thrombotic thrombocytopenic purpura in 166 pregnancies: 1955-2006. Am J Obstet Gynecol 2008;199:98104. [PubMed] [CrossRef]

11. Shibagaki Y, Fujita T. Thrombotic microangiopathy in malignant hypertension and hemolytic uremic syndrome (HUS)/thrombotic thrombocytopenic purpura (TTP): can we differentiate one from the other? Hypertens Res 2005;28: 89-95. [PubMed] [CrossRef]

This work is licensed under the Creative Commons Attribution-NonCommercial-NoDerivs 4.0 Unported (CC BY-NC-ND4.0) License. To view a copy of this license, visit http://creativecommons.org/licenses/by-nc-nd/4.0/ or send a letter to Creative Commons, PO Box 1866, Mountain View, CA 94042, USA.

Publisher's Note: The content of this publication does not necessarily reflect the views or policies of the publisher, nor does any mention of trade names, commercial products, of organizations imply endorsement by the publisher. Scientific and legal responsibilities of published manuscript belong to their author(s). The publisher remains neutral with regard to jurisdictional claims in published maps and institutional affiliations. 